\title{
Sealing ability of hydroxyapatite as a root canal sealer: in vitro study
}

\author{
Widowati Witjaksono, ${ }^{1,6}$ Lin Naing, ${ }^{2}$ Ema Mulyawati, ${ }^{3}$ AR. Samsudin, ${ }^{4}$ and Mon Mon Tin Oo ${ }^{5}$ \\ ${ }^{1}$ Department of Restorative Dentistry School of Dental Sciences Universiti Sains Malaysia \\ 2 Institute of Medicine National University of Brunei Darussalam \\ ${ }^{3}$ Department of Conservative Dentistry, Gadjah Mada University, Indoensia \\ ${ }^{4}$ Department of Oral Surgery and ${ }^{5}$ Department of Community Dentistry School of Dental Sciences Universiti Sains Malaysia \\ 6 Department of Periodontic, Faculty of Dentistry Airlangga University, Indonesia
}

\begin{abstract}
Hydroxyapatite (HA) is the most thermodynamically synthetic calcium phosphate cement, and has indicated useful as a sealer because can seal a furcation perforation, is shown to be biocompatible and also has potential to promote the healing of bone in endodontic therapy. The objective of this study is to determine the sealing ability of HA produced by School of Engineering, Universiti Sains Malaysia (USM) when used as a sealer in root canal obturation, compare with Tubli-seal (Zinc-Oxide base) and Sealapax (Calcium Hydroxyde base) sealers. Forty five single rooted human anterior teeth were instrumented and randomly divided into three experimental groups of 15 teeth each. All teeth in the experimental groups were obturated with laterally condensed gutta percha technique. Teeth in the first group were sealed using Zinc-Oxide ( $\mathrm{ZnO}$ ) based sealer and those of second group using Calcium Hydroxide (CaOH) based root canal sealer. Third experimental group was sealed using HA from School of Engineering USM. Teeth were then suspended in $2 \%$ methylene blue. After this, teeth were demineralized dehydrated and cleared. Linear dye penetration was determined under magnifying lense with calibrated eye piece. Statistical analyses of the linear dye penetration were performed with Kruskal Wallis test. The intergroup comparison between HA and $\mathrm{ZnO}$ groups and $\mathrm{CaOH}$ groups were analyzed by Mann-Whitney test. The dye penetration for group which were sealed with HA exhibited the lowest penetration and it showed that there was a statistically significant difference both between $\mathrm{HA}$ and $\mathrm{ZnO}$ groups and also between HA and $\mathrm{CaOH}$ groups $(p<0.001)$.In conclusion, it was found that value added HA based endodontic material which were produced by USM can be used as a root canal sealing materials when it used in combination with epoxy resin since it leaked comparatively less as compared to $\mathrm{ZnO}$ and $\mathrm{CaOH}$ sealers. Before reaching a definitive conclusion, this material requires further extensive exploration both clinically and in vitro.
\end{abstract}

Key words: apical seal, endodontic sealers, micro leakage

Correspondence: Widowati, Department of Restorative Dentistry, School of Dental Sciences Universiti Sains Malaysia, Health Campus 16150 K.Kerian, Malaysia. E-mail: widowati@kb.usm.my

\section{INTRODUCTION}

Root canal obturation consists of placing an inert filling material in the space previously occupied by pulp tissue. To achieve successful endodontic therapy, it is important to obturate the root canal system completely. Gutta-percha is used with various techniques for obturation of the root canal system. Throughout the years, a variety of techniques using gutta-percha have been developed for root canal fillings. These techniques include lateral condensation, warm vertical condensation, and injectable thermoplasticized. Investigators have evaluated the apical seals obtained by these various gutta-percha filling techniques. ${ }^{1}$ Lateral condensation remains the most widely accepted and used obturation technique. ${ }^{2}$ Almost all other techniques are compared to it to evaluate success. It seems that lateral condensation is a gold standard for obturation. Based on that reasons, this study will use lateral condensation for root canal obturation.

In root canal obturation various materials have been used. The most frequent material used is gutta percha in combined with a root canal sealer. It must have ideal properties to be used for root canal obturation, as biocompatibility and sealing ability fundamental to promote apical and periapical tissue repair. ${ }^{3}$ Many materials are used for root canal sealer, but none of the available sealer consistency prevents leakage. ${ }^{4}$. The hermetic sealing of the root canal space is one of the objectives in root canal therapy. ${ }^{5}$

The most common cause of failure involving endodontic therapy can be attributed to the lack of an apical seal leading to leakage at the apex. Effective endodontic obturation thus, must provide a dimensionally stable, inert fluid tight apical seal that will eliminate any portal of communication between the canal space and the surrounding periapical tissues through the apical foramen. ${ }^{6}$

Hydroxyapatite is the most thermodynamically stable synthetic calcium phosphate cement. ${ }^{7}$ A calcium phosphate cement has indicated that is useful as a sealer because can seal a furcation perforation, is shown to be biocompatible and also has potential to promote the healing of bone in endodontic treatment. ${ }^{8}$ Recently, most of the sealers commonly used contains zinc oxide or calcium hydroxide as a base ingredient of the powder. ${ }^{9}$ 
The present study was thereby designed to determine the sealing ability of hydroxyapatite when used as a sealer in root canal obturation, compare with zinc-oxide base and calcium hydroxide base. Therefore, it would be interesting to examine whether or not hydroxyapatite is able to act as a root canal sealer. The rationale is that if adequate sealing is obtained, this material has the potential to be clinically useful.

\section{MATERIALS AND METHOD}

This study was designed to evaluate the in vitro sealing abilities of endodontic materials. The following materials were selected and grouping for the study.

Materials: Tubli_Seal TM sealer (SybronEndo, Kerr/ USA). A zinc-oxide based root canal sealer ( $\mathrm{ZnO})$ Sealapex ${ }^{\mathrm{TM}}$ sealer (SybronEndo, Kerr/USA). A calcium hydroxide based root canal sealer $\left(\mathrm{Ca}(\mathrm{OH})_{2}\right)$ Hydroxyapatite (HA) (from School of Engineering, Universiti Sains Malaysia/ USM) and were mixed with epoxy resin (Dentsply, DeTrey). This type of HA were used as part of a larger study (not yet published) in many fields and clinical trials.

Instruments: Ultrasonic scaler, bone's cutting, contra angle hand piece, burs, endodontic box, glass lab, cement spatula, plastic filling instruments, tweezer, explorer, paper point, magnifying lense $10 \times$, le crown mesh knife.

The study was carried out in vitro on forty-five extracted human single rooted, noncarious anterior teeth which were collected from the outpatient department of oral and maxillofacial surgery, School of Dental Sciences, Universiti Sains Malaysia. All external debris were removed with an ultrasonic scaler.

All teeth randomly divided into 3 groups each is 15 teeth. The crown were separated from the root until the length of the roots were $14 \mathrm{~mm}$ and store in saline. The pulps were broch and the root canals were prepared by Step-back technique with working length $13 \mathrm{~mm}$ until no:80 file with Master Apical File (MAF) no 50. After the use of each instrument (file), the root canals were irrigated with $1 \mathrm{ml} \mathrm{H}_{2} \mathrm{O}_{2} 3 \%$ and $1 \mathrm{ml} \mathrm{NaOCl} 2.5 \%$ and dry with paper point and ready for root canal filling. The sealer were mixed according the manufacture's directions. Hydroxyapatite granules were mixed up with epoxy resin liquid for hardener. The sealer was put along the lentulo plugger and coated to the inner walls of the canal by moving lentulo plugger clockwise according the groups, group $\mathrm{A}$ ( $\mathrm{ZnO}$ based root canal sealer), group $\mathrm{B}\left(\mathrm{Ca}(\mathrm{OH})_{2}\right)$ based root canal sealer and group C (HA from School of Engineering USM). One third apical of gutta percha master cone (no. 50) was coated with sealer and seat in the canal to the full working length. The canal were obturated with lateral condensation technique. A finger spreader was inserted into the root canal to a level that was $-1 \mathrm{~mm}$ short of the working length. The root canal was filled with accessory cones until the entire canal was obturated. The access cavities of teeth in all groups were then filled with zinc polycarboxylate cement and hydraulic temporary restorative, then the root were immersed in saline solution for 4 weeks at $37^{\circ} \mathrm{C}$. After storage, the roots were double coated with nail polish, with the exception of the apical $2 \mathrm{~mm}$. Specimens used for the dye leakage test were placed in $2 \%$ methylene blue solution $(37 \mathrm{C}, \mathrm{pH} \&$ ) for 48 hours. The roots were then taken from the dye solution, remove the nail polish with le crown mesh knife, washed and dried with compressed air. The depth of dye penetration were evaluated with clearing method. ${ }^{10}$

All the teeth were immersed in HNO3 5\% for 72 hours for teeth demineralized. HNO3 was changed with the fresh one every 24 hours. The teeth were then placed in alcohol $96 \%$ for 48 hours for teeth dehydration, and every 24 hours alcohol was changed with the fresh one. The final stage was clearing. ${ }^{10}$ All the teeth were placed in methyl salicylate, until dye penetration were able measured visually. Apical leakage was measured from the apex to the most coronal extent of dye penetration (Figure 1, 2, and 3). Linear dye penetration was measured under magnifying lense with calibrated eye piece and analyse by Kruskal Wallis test. The intergroup comparison between hydroxyapatite and zinc oxide groups and calcium hydroxide groups data analyzed by Mann-Whitney test.

\section{RESULTS}

In the present study, measurements of maximum linear dye penetration were made to quantify the relative leakage (Figure 1, 2, 3). Dye penetration data for all the three groups are summarized in table 1 . In group $C$ teeth which were filled with laterally-condensed gutta-percha and hydroxyapatite (HA) sealer exhibited the lowest minimum-maximum (min-max) value of dye penetration. The min-max of dye penetration for group $\mathrm{C}(\mathrm{HA})$ was between $0-1 \mathrm{~mm}$. The min-max of dye penetration for group A teeth which were filled with laterally-condensed guttapercha and zinc oxide $(\mathrm{ZnO})$ base sealer was between 1-3 $\mathrm{mm}$. The corresponding values for group B teeth which were filled with laterally condensed gutta-percha and calcium hydroxide $\left(\mathrm{Ca}(\mathrm{OH})_{2}\right)$ base sealer was also between 1-3 mm. Ten samples in group C (HA) showed no dye penetration whereas all samples in group A and B showed dye penetration. The comparison of the three study groups using Kruskal Wallis test (Table 2) revealed that there were at least one significant difference among the study groups $(\mathrm{p}<0.001)$. Further Mann-Whitney test (post-hoe multiple comparisons between two groups) (Table 3 ) revealed that HA group has significance lesser penetration compared to $\mathrm{ZnO}$ or $\mathrm{Ca}(\mathrm{OH})_{2}$ groups $(\mathrm{p}<0.001)$. 


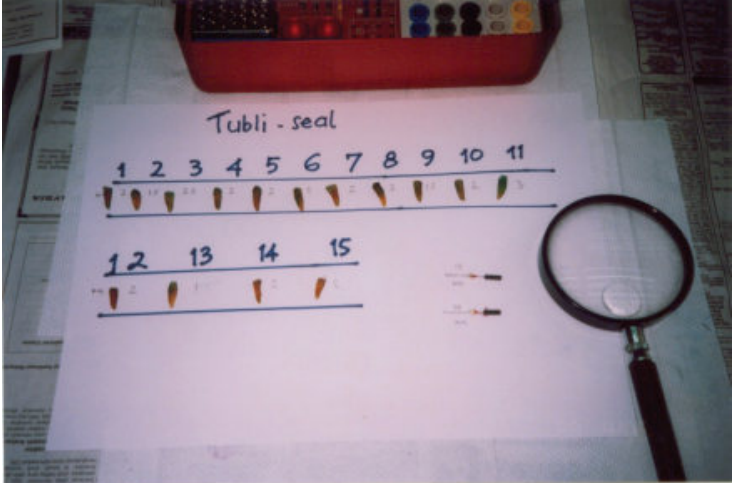

Figure 1. Measurement of apical leakage in $\mathrm{ZnO}$ base (group A).

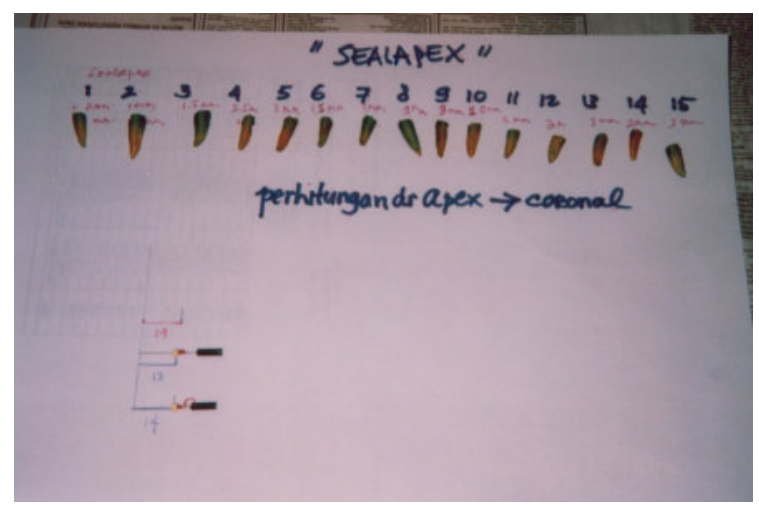

Figure 2. Measurement of apical leakage in $\mathrm{Ca}(\mathrm{OH})_{2}$ base (group B).

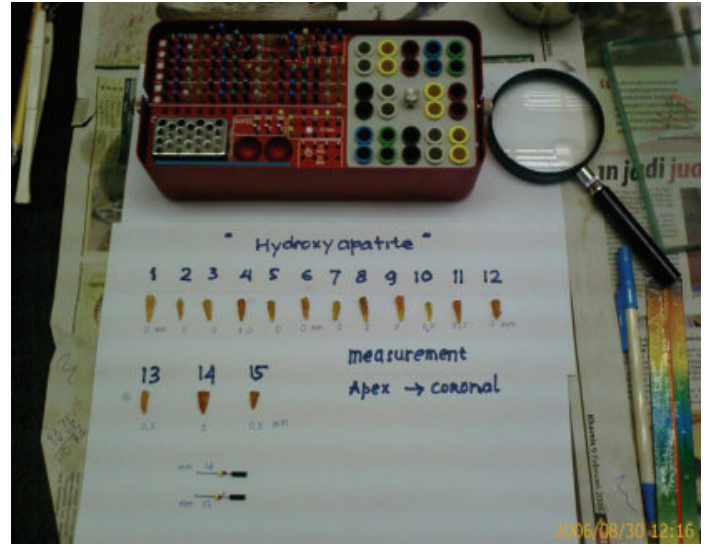

Figure 3. Measurement of apical leakage in Hydroxyapatite.

\section{DISCUSSION}

HA is one of the ceramic materials commercially used for orthopaedic and dental implants, and it forms the principal mineral component of bone and comprises $60 \%$ to $70 \%$ of the calcified skeleton. It's chemical composition is $\mathrm{Ca} 10(\mathrm{PO} 4) 6(\mathrm{OH}) 2$ and it has been produced synthetically since the early 1970's and used clinically for the last 20 years. ${ }^{11,12}$ It has received considerable attention over the past two decades primarily because of it's excellent biocompatibility with hard tissues. ${ }^{13,14}$ and when placed in contact with viable bone, result in osteoconduction

Table 1. Amount of dye penetration in group A, B and C (mm)

\begin{tabular}{rrrr}
\hline & \multicolumn{3}{c}{ Amount of dye penetration (in mm) } \\
\cline { 2 - 4 } Specimen no of each group & $\begin{array}{c}\text { Group A zinc oxide base } \\
(\mathrm{ZnO})\end{array}$ & $\begin{array}{c}\text { Group B calcium hydroxide } \\
\left(\mathrm{Ca}(\mathrm{OH})_{2}\right)\end{array}$ & $\begin{array}{c}\text { Group C Hydroxyapatite } \\
\text { (HA) }\end{array}$ \\
\hline 1 & 2 & 2 & 0 \\
2 & 1.5 & 1 & 0 \\
3 & 2.5 & 1.5 & 0 \\
4 & 2 & 2.5 & 0 \\
5 & 2 & 3 & 0 \\
6 & 1 & 1.5 & 0 \\
7 & 2 & 3 & 0 \\
8 & 3 & 2 & 0 \\
9 & 1.5 & 2 & 0.5 \\
10 & 2 & 2 & 0.5 \\
11 & 3 & 3 & 0 \\
12 & 2 & 2 & 0.5 \\
13 & 1 & 3 & 0 \\
14 & 2 & $1-3$ & 0.3 \\
15 & 2 & $2.0(1.0)$ & $0-1$ \\
Min-Max & $2-3$ & 2 & $0.0(0.5)$ \\
\hline Median (IQR) & $2.0(0.5)$ & & 0 \\
\hline
\end{tabular}


Table 2. Comparison of dye penetration between study groups (mm)

\begin{tabular}{|c|c|c|c|c|c|}
\hline \multirow{2}{*}{ Group } & \multirow{2}{*}{$\mathrm{n}$} & \multicolumn{2}{|c|}{ Dye Penetration } & \multirow{2}{*}{$\mathrm{X}^{2}$ Stat. (df) } & \multirow{2}{*}{ P value ${ }^{a}$} \\
\hline & & Median (IQR) & Min.-Max. & & \\
\hline $\mathrm{ZnO}$ & 15 & $2.0(0.5)$ & $1-3$ & \multirow{3}{*}{$\begin{array}{c}31.00 \\
(2)\end{array}$} & \multirow{3}{*}{$<0.001$} \\
\hline $\mathrm{Ca}(\mathrm{OH})_{2}$ & 15 & $2.0(1.0)$ & $1-3$ & & \\
\hline $\mathrm{HA}$ & 15 & $0.0(0.5)$ & $0-1$ & & \\
\hline
\end{tabular}

${ }^{\mathrm{a}}$ Kruskal Wallis test

$\mathrm{IQR}=$ Interquartile range; Min. = Minimum; Max. = Maximum

Table 3. Comparison of dye penetration between Hydroxyapatite (HA) and others

\begin{tabular}{lcc}
\hline Comparison & Z Stat. & P value $^{\mathrm{a}}$ \\
\hline $\mathrm{ZnO}$ vs HA & -4.76 & $<0.001$ \\
$\mathrm{Ca}(\mathrm{OH})_{2}$ vs HA & -4.77 & $<0.001$ \\
\hline
\end{tabular}

${ }^{a}$ Mann-Whitney test; $P$ value is adjusted using Bonferroni procedure for multiple comparison

and osteointegration. ${ }^{15,16}$ HA does not cause a chronic inflammatory respons, toxic reactions or a foreign body giant cell reaction. ${ }^{12}$ Although HA is a promising implant material, the greatest stumbling block to it's wider application and utilization is the brittleness of the material and it's low strength for load-bearing applications. ${ }^{17}$ Thus the material used in this study is the value added HA based material which were produced by a group of scientist at the School of Engineering Universiti Sains Malaysia (USM). The pure HA has been added with zirconia and other additional components, hot pressed and then sintered at a temperature of $1300{ }^{\circ} \mathrm{C}$, to increase the toughness and strength of HA ceramic. Composites formed by HA ceramic in combination with zirconia have been proven not to produce any local or systemic adverse reactions or any cytotoxix effects in various in vivo studies. ${ }^{18}$ This material showed no decrease in strength after ageing up to 1 year, which is in agreement with the study done by some investigators in $1993 .^{19}$

It has been recognized for decades that the ideal end result of root canal therapy would be a closure of the apical foramen with reparative cementum. The goals for stability of successful endodontic therapy are total obliteration of the canal and perfect sealing of the apical foramen at the dentino-cemental junction and accessory canals at locations other than the root apex with an inert, dimensionally stable and biologically compatible material. ${ }^{20}$ According to other researchers, ${ }^{21}$ endodontic sealers are used to eliminate the interface between the gutta-percha and the dentinal walls. Thus, the quality of the filling depends largely on the sealing capacity offered by sealers. ${ }^{22,23}$

From this study an average leakage values of $\mathrm{Zn} O$ base sealer and $\mathrm{CaOH}$ base sealer both were minimum of $1 \mathrm{~mm}$ to maximum of $3 \mathrm{~mm}$. The lesser value of dye penetration shown by value added HA sealer in the present study may be because of the better sealing abilities of HA. One possible explanation for this observed difference may be that HA has ability to bind strongly with natural bone tissue, ${ }^{24}$ and synthetic HA has the same chemical composition as biological HA and thus mimics many properties of natural bone. ${ }^{25}$ As for epoxy-resin based endodontic sealers to the human dentin showed a higher capacity to attach to the dentinal walls than other endodontic sealers and provide bonding between it and gutta-percha points. ${ }^{26}$ However the exact mechanism by which HA is incorporation with epoxy resin, then can be function as a good root canal sealer in the present study remain far from clear. It would be necessary to carry out further studies in order to make a larger evaluation of these value added HA based endodontic materials as well as their potential benefits. The in vivo evaluation should be done to assess the reaction to this value added HA as compared to the pure HA.

It can be concluded from this study that the value added HA based endodontic material can be used as a root canal sealing materials when it used in combination with epoxy resin since it leaked comparatively less as compared to $\mathrm{ZnO}$ and $\mathrm{CaOH}$ sealers. Before reaching a definitive conclusion this material requires further extensive exploration both clinically and in vitro.

\section{ACKNOWLEDGEMENTS}

The authors acknowledge the Universiti Sains Malaysia for funding this research as a short term grant in the year 2006-2007. Special thanks to Ir. Endro for help with the special work.

\section{REFERENCES}

1. Goodman A, Schilder H, Burg, KJL, Porter S. The thermo mechanical properties of gutta-percha, II: The history and molecular structure of gutta-percha. Oral Surg Oral Med Oral Path Oral Radiol Endod 1974; 37:954-95.

2. Dummer PMH. Comparison of undergraduate endodontic technique programs in the United Kingdom and in some schools in Europe and the United States. Int Endod J 1991; 24:169-77.

3. Duarte MAH, Demarchi ACCO, Giaxa MH, Kuga MC, Fraga SC, Souza LCD. Evaluation of $\mathrm{pH}$ and calcium ion release of three root canal sealers. J Endo 2000; 26(7):389-90.

4. Mannocci F, Ferrari M. Apical seal of root obturated with laterally condensed gutta-percha, epoxy resin cement and dentin bonding agent. J Endod 1998; 24(1):41-4. 
5. Goldberg F, Massone EJ, Artaza LP. Comparison of the sealing capacity of three endodontic filling techniques. J Endod 1995; 21(1):1-3.

6. Hovland EJ, Dumsha TL. Leakage evaluation of in vitro of the root canal cement seal apex. Int Endodon J 1985; 18:179-92.

7. Hayashi Y, Imai M, Yanagiguchi K, Viloria IL, Ikeda T Hydroxyapatite applied as direct pulp capping medicine substituted for osteodentin. J Endod 1999; 25(4):225-9.

8. Cheng AM, Chow LC, Takagi S. In vitro evaluation of calcium phosphate cement root canal filler/sealer. J Endod 2001 27(10):6133-5.

9. Ingle JI, West JD. Obturation of the radicular space. In: Ingle JI, Bakland LK, editors. Endodontics. $4^{\text {th }}$ ed. Baltimore: Lea and Febiger; 1994. p. 229-57.

10. Robertson D, Leeb IJ, Mc Kee M, Brewer E. A clearing technique for the study of root canal systems. J Endod 1980; 6:421-4.

11. Jarcho M. Calcium phosphate ceramics as hard tissue prosthetics. Clin Orthop Rel Res 1981; 157(9):259-78.

12. Constantino PD, Friedman CD, Lane A. Synthetic biomaterial in facial plastic and reconstructive surgery. Facial Plast Surg 1993 9(1):1-15.

13. Wozney JM, Rozen V. Bone morphogenetic protein and bone morphogenetic protein gene family in bone formation and repair Clin Orthop Rel Res 1998; 346:26-37.

14. Suchanek W, Yoshimura M. Processing and properties of Hydroxyapatite-based biomaterials for use as hard tissue replacement implants. J Mater Res 1998; 13(1):94-117.

15. Burg KJL, Porter S, Kellam JF. Biomaterial developments for bone tissue engineering. Biomaterials 2000; 21:2347-59.
16. Green D, Walsh D, Mann S, Oreffo ROC. The potential of biomimesis in bone tissue engineering: lessons from the design and synthesis of invertebrate skeletons. Bone 2002; 30(6):810-15.

17. Muralithran G, Ramesh S. The effects of sintering temperature on the properties of hydroxyapatite. Ceram Int 2000; (26):221-30.

18. Piconi C, Maccauro G. Zirconia as a ceramic biomaterial. Biomaterials 1999; 20:1-25.

19. Shimizu K, Oka M, Kumar P. Time-dependent changes in the mechanical properties of zirconia ceramic. J Biomed Mater Res 1993; 27:729-34.

20. Paul Wesselink. Root filling techniques. In: Bergenholtz. G, Bindslev $\mathrm{PH}$, Reit Claes, editors. Text book of endodontology. Oxford: Blackwell Publishing Company; 2003. p. 286-90.

21. Timpawat S, Amornchat C, Trisuwan WR. Bacterial coronal leakage after obturation with three root canal sealers. J Endod 2001; 37:36-9.

22. Oliver CM, Abbot PV. An in vitro study of apical and coronal microleakage of laterally condensed gutta-percha with Ketac-Endo and AH-26. Aust Dent J 1998; 43:262-8.

23. Cobankara FK, Adanir N, Belli S, Pashley DH. A quantitative evaluation of apical leakage of four root-canal sealers. Int Endod J 2002; 35:979-84.

24. Dalby MJ, Di Silvio L, Harper EJ, Boneld W. Initial interaction of osteoblasts with the surface of a hydroxyapatite-poly (methyl methacrylate) cement. Biomaterials 2001; 22:1739-47.

25. Jarcho M. Rertrospective analysis of hydroxyapatite development for oral implant applications. Dent Clin North Am 1992; 36:19-26.

26. Pecora JD, Cussioli AL, Gurisoli DMZ, Marchesan MA, Sousa-Neto MD, Brugnera-Junior A. Evaluation of Er: YAG Laser and EDTAC on dentin adhesion of six endodontic sealers. Braz Dent J 2001; 12(1):27-30. 